Article (refereed) - postprint

Welch, David; Scott, David. 2017. Observations on bark-stripping by red deer in a Picea sitchensis forest in western Scotland over a 35-year period.

(C) 2017 Taylor \& Francis

This version available http://nora.nerc.ac.uk/514901/

NERC has developed NORA to enable users to access research outputs wholly or partially funded by NERC. Copyright and other rights for material on this site are retained by the rights owners. Users should read the terms and conditions of use of this material at

http://nora.nerc.ac.uk/policies.html\#access

This is an Accepted Manuscript of an article published by Taylor \& Francis Group in Scandinavian Journal of Forest Research on 03/11/2016, available online:

http://dx.doi.org/10.1080/02827581.2016.1247464 
Publisher: Taylor \& Francis \& Informa UK Limited, trading as Taylor \& Francis Group

Journal: Scandinavian Journal of Forest Research

DOI: $10.1080 / 02827581.2016 .1247464$

\title{
Observations on Bark-stripping by Red deer in a Picea sitchensis forest in Western Scotland over a 35-year Period.
}

\section{David Welch and David Scott}

Centre for Ecology and Hydrology, Edinburgh Research Station, Bush Estate, Penicuik, Midlothian, EH26 0QB, UK.

\begin{abstract}
The impact of bark-stripping by red deer on an 1825 ha plantation of Picea sitchensis is reported. Monitoring began in 1978 with initially 6500 trees at 37 sites; by 2014 only 10 sites remained due to felling. Sites became vulnerable to bark-stripping once the trees reached 7 years age, and from then until felling at age c. 45 years incidence rates averaged 1\% of the trees damaged yearly. Intense damage at a site in a year ( $>2 \%$ trees damaged) was often followed by intense damage next year, but on average $53 \%$ of sites were undamaged in a year. Many trees suffered repeat wounding, which reduced final impact by c. 30\% compared to the theoretical impact calculated from annual damage and damage duration. The trees bark-stripped were on average smaller than plot mean girths once these means exceeded $20 \mathrm{~cm}$; this had only minor effect on final impact since bark-stripped small trees had similar mortality to undamaged small trees. Most wounds $(>90 \%)$ were small $\left(<180 \mathrm{~cm}^{2}\right)$ and healed quickly, so were unlikely to develop decay. Larger wounds never healed in less than 8 years, but the proportion healed increased progressively from 10 to 20 years after wounding.
\end{abstract}

Keywords: Bark-stripping, Picea sitchensis, red deer, Scotland, wound healing

\section{Introduction}

Bark-stripping by deer on conifers has been reported from many Northern countries and sometimes has caused serious economic losses (Gill 1992; Akashi \& Nakashizuka 1999; Verhayden et al. 2006; Månsson et al. 2013). In Gill`s review Picea sitchensis was found to be less severely damaged than other conifers especially P. abies, Pinus sylvestris and Pseudotsuga menziesii. Most of the sites contributing to this conclusion were Scottish, but a recent Irish suryey found similarly low rates of bark-stripping in commercial plantations of $P$. sitchensis (Murphy et al. 2013).

Many reports on bark-stripping have been surveys on its incidence and patchiness, but deciding whether bark-stripping is ultimately causing significant damage in commercial forests needs assessment of four key factors over longer periods: the length of time over which the bark-stripping occurs, the size of the trees or trunks damaged, the frequency of repeat damage, and the recovery of the wounds. Financial impact can also be affected by the position of the wounds, the products ranging from pulp to high-quality timber the forests are producing, the possible management measures that can be employed to minimise crop losses, and the sentiment of buyers observing bark-stripping wounds and suspecting timber defects.

Several workers have studied selectivity in the size of the trunks being bark-stripped by deer, but for conifers other than $P$. sitchensis. Smaller trees have usually been found to 
suffer significantly greater incidences than larger ones, e.g. by Akashi \& Terazawa (2005) for Abies sachalinens and Larix kaempferi damaged by sika deer in Japan, and by Vospernik (2006) for P. abies damaged by red deer in Austria. Vospernik found that trees of $16 \mathrm{~cm}$ girth were the most severely affected but also reported some previous Austrian studies that had peak damage probability at girths up to $48 \mathrm{~cm}$. In Japanese subalpine forests Yokoyama et al. (2001) showed that selection by sika deer varied sharply between five different conifer species and also between two study areas for one of the species, Picea jezoensis, but they did not make measurements on bark qualities that might have explained these differences. In Sweden Månsson \& Jarnemo (2013) found that the trees of P. abies bark-stripped by red deer in two districts were significantly smaller than undamaged trees, and also had thinner bark and fewer branches along the vulnerable section of trunk.

Repeat bark-stripping occurs regularly on P. abies. In Austrian forests Büchsenmeister (1995) found during five years of observations that each year repeat barkstripping amounted to 38\% of the first-time stripping recorded. And in Sweden trees with old wounds suffered new damage significantly more often than expected in a district with moderate incidence of bark-stripping (Månsson \& Jarnemo 2013), but how long the old wounds had remained visible was not assessed. These findings establish that effective damage over whole rotations can potentially be significantly modified by the deer`s selectivity, thus it is very desirable to find out for the combination of $P$. sitchensis and red deer how important are these factors, and also to assess wound recovery and the longevity of damage incidence.

A long-term study of the impact of red deer on P. sitchensis began in Glenbranter Forest in Western Scotland in 1978. Early papers reported on the incidence of bark-stripping in stands of different ages (Welch et al. 1987) and on wound sizes (Welch et al. 1988). Later came reports on the healing of wounds up to 15 years old (Welch et al. 1997) and on the survival and performance of bark-stripped trees over periods of up to 16 years (Welch et al. 1998), only very minor differences being found between damaged and undamaged trees. Then in 1998 a sample of trees was felled to assess how timber quality had been affected by bark-stripping (Welch et al.2008). In Britain stands of $P$. sitchensis are now often harvested soon after they become 40 years old, and hence many of the remaining study sites in Glenbranter will soon be felled. Thus there is a unique opportunity to make a full assessment of the incidence of bark-stripping, its selectivity, repeat damage and wound recovery, the findings being especially valuable due to the considerable length of the observation period.

\section{Materials \& methods}

\section{Study Forest}

Glenbranter Forest ( $56^{\circ} 07^{\prime} \mathrm{N} 5^{\circ} 03^{\prime} \mathrm{W}$ ) lies in the Cowal peninsula, Argyllshire, close to the west coast of Scotland. It straddles the diverging valleys of Glen Branter and Glen Shellish, and is roughly circular with area $1825 \mathrm{ha}$. Altitude ranges from $90 \mathrm{~m}$ to $410 \mathrm{~m}$. The climate is moderately oceanic (July mean temperature $14.7^{\circ} \mathrm{C}$, January mean $1.4^{\circ} \mathrm{C}$ ) and wet (c. $2200 \mathrm{~mm}$ annual rainfall). The soils are relatively fertile, and vary from brown earths to gleys and peaty podsols.

The forest is now stocked chiefly with $P$. sitchensis. Afforestation started at low altitudes in the 1920s and extended to higher ground gradually in the 1950s, 1960s and 1970s. At first $P$. abies was the main species planted, but since the 1950s almost all plantings have been $P$. sitchensis. A major storm in 1967 blew down many maturing stands, but 
restocking soon followed. Most stands produce some logs that convert to good-quality timber, though much of the harvested crop is used for pulp.

Red and roe deer have been present in the forest throughout the study. Their density and distribution within the forest was assessed by regular counts of pellet groups on fixed plots from 1978 to 1984, giving a mean estimated presence of 0.02 red deer ha' ${ }^{-1}$ for the older forest stages with sparse or no ground vegetation, and 0.15 red deer ha ${ }^{-1}$ for the younger stages and rides with a complete field layer (Welch et al. 1990). Since 1984 numbers appear to have fallen slightly, and the forest managers now consider deer damage to be only a moderate problem. For the whole Cowal district there is no longer a deer management group gathering data from counts and culls and the area is not included in the map of red-deer densities provided by the Deer Commission Scotland (Edwards \& Kenyon 2013). However for the district immediately to the north of Cowal an average overall density of 0.08 red deer $\mathrm{ha}^{-1}$ has been estimated for the 2002-2016 period (Inveraray \& Tyndrum Deer Management Group 2016).

The red deer in Glenbranter Forest feed on a wide variety of plants, found from examining the rumens of 283 deer shot from 1978 to 1983 (Staines et al. 1985). Graminoids contributed about half the total volume of rumen content year-round, with ericoids next in importance particularly Calluna vulgaris. During winter, ericoids were more eaten than graminoids and fern intake was appreciable. Conifer shoots were browsed largely in spring; conifer bark was not found in any of the rumens examined, implying that bark-stripping is a rare event occurring in special circumstances.

The forage regularly eaten by red deer is widely available in Glenbranter Forest since even in the older forest stages (thicket, pole and high forest) there are access rides and areas of windblow with ground vegetation. Also belts of unplanted high ground lie between the main lengths of forest that extend along two diverging valleys (map in Welch et al. 1990). The forest management compartments ayeraged c. 10 ha in size during the early years of study, but have become larger because felling is now done by large machines needing fewer but stronger access roads. However the home ranges observed for red deer in the forest (Staines et al. 1985) still much exceed the size of blocks that currently lack ground vegetation.

\section{Monitoring}

Observations began in 1978 when 40 forest sites were chosen and set up. All stages in forest growth were monitored, sites for each stage being selected randomly out of all the possible 1.5 ha units (range 1-2 ha) available from notionally dividing all sub-compartments belonging to the stage. For the actual observations six permanent plots in each site were randomly chosen. The size of plots varied between forest stages to allow for stocking density, our aim being to have at least 25 trees on each plot. Monitoring continued at sites until they were felled or severely affected by windblow; the last year reported is 2014. Just 2 further sites were added after 1978, being set up in 1979 in newly planted compartments that were previously open hill. Initially 6500 trees of $P$. sitchensis were monitored plus 1650 trees of $P$. abies present in varying amounts in 12 older pole-stage and high-forest sites. These older sites were felled in the early years of our study, and this paper is concerned only with bark-stripping on $P$. sitchensis that grew in 37 sites.

Sites were checked annually for bark-stripping damage, though early in the study checks were more frequent; after 2000 a few remote sites have been visited only at two- or 
three-year intervals, the year of any new damage being estimated. On finding wounds we measured the girth of the damaged trunk at breast height $(1.3 \mathrm{~m})$ and wound length and breadth. We also recorded the position of wounds and whether or not xylem had been exposed. Thereafter the condition of wounds was assessed yearly during the checks for fresh bark-stripping.

All the trees present on the sites had their girths measured at regular intervals, enabling the selectivity of the deer in bark-stripping to be calculated. Initially girthing took place every year, but for most of the study it was done every three years and plot mean girths for intermediate years were estimated when compiling the data sets on selectivity.

The numbers of trees available to be wounded and the numbers of wounds on which to observe healing fell during the study period due to deaths and wind-blow as well as the total felling of sites. This was handled differently depending on the analyses. For examining the long-term trends in the yearly incidence of bark-stripping we regrouped the five forest stages of our earlier papers (Welch et al. 1987; Welch et al. 1988) into three stand types since otherwise the numbers of trees damaged in the older stages would have been too few for useful averaging. We combined the pre-thicket and thicket stages, their sites aged 9-14 yr and 15-28 yr, respectively, in 1978, and the pole and high forest stages, aged 29-44 yr and $>44 \mathrm{yr}$, respectively, in 1978. For the three stand types only incidence averages based on five or more sites are included in Figure 1. The last incidence average for pole and high forest was based on 980 trees and the last for pre-thicket and thicket had 435 trees. For individual sites we compared their actual final incidence of damage with a theoretical incidence calculated from the mean annual incidence of damage at the site and the duration over which it was observed.

For analysing repeat bark-stripping, we arbitrarily chose to compare 20-year periods after wounding with the rates of wounding recorded in the first 20 years of our monitoring. Only sites that had been observed for at least 30 years were included in this data set. For selectivity in wounding, i.e., which trees were bark-stripped compared to what was available on the plots, all observed occurrences were used in comparisons of wounded-trunk girth to plot mean trunk girth. To examine wound healing we used all available wounds for as long as their trees were standing, but have reported only for the establishment stand type and the pre-thicket and thicket stand type, there being insufficient long-observed wounds in the pole and high-forest stage. Wounds were judged to be healed when no xylem was visible and their newly developed bark had become smooth and uniform. We also compared healing between trees younger and older than 20 years of age at wounding, and between wounds of three size classes. These classes, $<60 \mathrm{~cm}^{2}, 60-179 \mathrm{~cm}^{2}$ and $>180 \mathrm{~cm}^{2}$, were found to be differentiated in our earlier analyses (Welch et al. 1997).

In this paper, tree age refers to the time since the trees were planted on our sites; their actual age is one or two years greater. Wound size is the product of the length and breadth of wounds and their actual size averages $10 \%$ less. The establishment stand type includes restocked sites as well as those (the majority) on ground that had not previously been cropped.

\section{Results}

\section{Occurrence of bark-stripping}


The annual incidence of bark-stripping averaged about $1 \%$ on the available trees of Picea sitchensis during our study. For the vulnerable years from age 8 to age 47 successive 10 -year means of incidence were $1.0 \%, 1.0 \%, 0.9 \%$ and $1.0 \%$, based on all the sites recorded. Yearly variation in incidence is shown for the three stand types in Figure 1, and only rarely did the mean annual rates reach $2 \%$ or fall below $0.3 \%$. For the establishment stand type low rates up to 1983 resulted from most sites being less than 8 years old and so not vulnerable. For the next 28 years to 2010, mean percentage incidence (with standard error) was $0.96 \pm 0.07$ for the establishment stand type and $1.03 \pm 0.10$ for the pre-thicket and thicket stand type. For these two stand types the yearly rates of damage were quite closely parallel, with a Pearson correlation coefficient of $0.541(P<0.01)$ for the 28-year period.

[Figure 1 near here]

Many sites suffered no bark-stripping damage in a year, and for stand types at least one site was undamaged in every year. The mean percentage occurrence of no bark-stripping in a year was $52 \%$ for establishment sites $(\mathrm{n}=442)$ and $49 \%$ for pre-thicket and thicket sites $(n=297)$. For pole and high forest sites $(n=97)$ mean occurrence of no damage was $72 \%$, the high forest sites having become much less vulnerable. But there was intense barkstripping on over $2 \%$ of the available trees in a year at some sites (Table 1 ). The mean occurrence of intense damage above this level was $17 \%$ for the 23 sites of the establishment and pre-thicket/thicket stand types. Over the whole study only in one year did $2 \%$ or more bark-stripping not occur in at least one site.

[Table 1 near here]

Intense bark-stripping in a year was followed by intense stripping in the next year at 12 sites (Table 1), and at two sites (EW2 and TD4) there were sequences of 6 and 10 years with intense damage. The average age for this intense damage occurring at sites ranged from 16 to 41 years, with a mean age of 26 years for the 22 sites. For sites of the establishment stand type the average ages for intense bark-stripping tended to be lower than for the older sites.

The heaviest incidence of bark-stripping in a year was 10.8\% at TD4, where 19 of 176 trees were wounded in 1984-85. Nine other recordings of annual incidence exceeded 5\%, these at four sites and in eight different years. For incidence greater than $4 \%$ there were 24 instances at 10 sites in 16 separate years. At two thicket sites that had spells of intense damage, TD2 and TD4, there were intervals of 11 and 15 years respectively when barkstripping was negligible or absent.

Many bark-stripped trees were bark-stripped again in subsequent years. By 2015 a total of 205 trees had suffered repeat wounding, 194 of them in the establishment and prethicket/thicket stand types. For the latter trees the distribution pattern of the times elapsing between first and second woundings is shown in Figure 2. The majority of repeat woundings occurred within six years of the initial wounding, and the average interval (with standard error) was $6.8 \pm 0.4$ years. Of the 194 trees that had been twice damaged, 50 suffered further bark stripping during the study period.

[Figure 2 near here]

The incidence of repeat bark-stripping on wounded trees was greater for most sites than the incidence of bark-stripping on all trees recorded during the first 20 years of our study (Table 2), which implies that wounded trees have a greater risk of being damaged than unwounded trees. The difference between repeat and initial bark-stripping incidences tended 
to be less at sites with greater damage, and was least at site EW2. At this site there was intense bark-stripping when the trees were 9 to 14 years old but damage never reached these levels again, which was reflected in the low average age of intense bark-stripping (18 years Table 1). A total of eight trees at five sites suffered repeat bark-stripping more than 20 years after the initial wounding, but these woundings were not counted in Table 2.

[Table 2 near here]

\section{Selectivity in Bark-stripping}

For all three stand types the mean difference between the girth of wounded trees and plot mean girth widened as plot girths increased (Table 3). The differences were highly significant $(P<0.001)$ for all classes made up of more than 30 trees apart from one class of the establishment stand type. This consisted of young stands with plot mean girths less than $20 \mathrm{~cm}$, and the trees being bark-stripped were slightly larger than the average size available on the plots $(P<0.05)$. Some wounded trees in all girth classes had girth difference contrary in sign to the class mean difference, and exceeded plot means by as much as $20 \mathrm{~cm}$ in the larger girth classes.

[Table 3 near here]

\section{Wound Healing}

The time taken for wounds to heal was affected by their size (Table 4). Large wounds greater than $180 \mathrm{~cm}^{2}$ never healed in less than 8 years, but smaller wounds had widely varying healing times. Differences between the establishment and pre-thicket/thicket stand types were minor, and also the few wounds observed sufficiently long on pole-stage trees showed similar healing times.

[Table 4 near here]

The slower recovery of larger wounds is also apparent in the percentages healed at 10, 15 and 20 years after wounding (Table 5), this data set including trees not healed, unlike the previous table. At 15 years after wounding $46 \%$ of wounds $>180 \mathrm{~cm}^{2}$ in size had not healed compared to $10 \%$ and $2 \%$ respectively for $60-179 \mathrm{~cm}^{2}$ and $<60 \mathrm{~cm}^{2}$ wounds. Twenty years after wounding $20 \%$ of them ( 8 of 41 trees) still had not healed. Trees that were younger than 20 years old when wounded appeared to have slightly quicker healing than older trees, but by 15 years after wounding the differences between the age groups were small.

[Table 5 near here]

Very large bark-stripping wounds exceeding $500 \mathrm{~cm}^{2}$ were incurred rarely (only 28 such wounds in 980 woundings observed in the whole study). For the establishment and prethicket/thicket stand types the 26 trees with very large wounds give information on fate (Table 6). Only three of these wounds became healed during the observations, but seven developed decay on part or all of the exposed xylem. Eighteen very large wounds still had xylem exposed at our last check; for the 8 wounds that became occluded the average time was 8 years but another 9 wounds had had xylem exposed for longer periods when last observed. The trees suffering very large wounds were quite variable in girth and their mean age of 28 years at wounding was slightly older than the average site age during our observations. Very few younger small trees with girth less than $20 \mathrm{~cm}$ incurred large single wounds, since they usually have branches at nodes which restrict wound length and cause the deer to take bark from one position rather than from the whole circumference of the tree.

[Table 6 near here] 


\section{Overall Impact}

At the 19 sites monitored for $>25$ years, the percentages of bark-stripped trees finally present were lower by about 30\% than the theoretical percentages calculated from mean annual rates of bark-stripping and duration (Table 7). There was little difference between final percentages calculated on the initial or on the final numbers of trees, reflecting the small change in tree number at most sites. On average $15 \%$ of trees were lost during our observations. But at four pre-thicket and thicket sites (ED3, EH1, EH5, TD4) 45 to $70 \%$ of the trees initially present had died or suffered wind-blow before the sites were felled. These sites were heavily stocked and many smaller trees died due to the intense competition. The many deaths did not result in lower final bark-stripped percentages, for example at site ED3 23 of the 167 trees present initially were later bark-stripped (13.8\%) and 11 of them were still alive out of 71 living trees (15.4\%) at our last recording.

[Table 7 near here]

Up to $11 \%$ of the trees present at the last recording had suffered bark-stripping wounds larger than $180 \mathrm{~cm}^{2}$ (Table 7). The sites that had the highest percentages of largewound trees had incurred the heaviest mean rates of damage during our study.

\section{Discussion}

This long present study in Glenbranter forest confirmed our early findings (Welch et al. 1987 and 1988): that around 1\% of the available P. sitchensis trees are being bark-stripped each year, that the duration of bark-stripping in a stand can be at least 40 years, that the majority of wounds are small $\left(<60 \mathrm{~m}^{2}\right)$, and that when the mean girths of stands exceed 20 $\mathrm{cm}$ the trees being wounded are on average the smaller ones. Besides strengthening the evidence for selectivity, the study gave a more precise measure of repeat bark-stripping, with $30 \%$ of the 645 bark-stripped trees in the establishment and pre-thicket/thicket stand types suffering at least one further wounding.

Interpreting our data on repeat damage (Table 2) is however problematic, because possibly red deer visited the stands to different extents in the periods compared and also the susceptibility of the trees may have changed as they grew older. But the increase in barkstripping shown in later years in Figure 1 was insufficient to explain the much greater incidence of repeat damage compared to first-time damage recorded in the first 20 years of observations. Only at three sites, those with greatest incidence, were the repeat incidences less than double the first 20-years incidences.

Very few other studies have considered repeat bark-stripping, a major problem being how to know or estimate the time period over which wounds have accumulated. Faber \& Thorson (1996) reported from spring surveys that $1.2 \%$ of available trees in plantations of $P$. sylvestris trees had been recently wounded and $15 \%$ of these damaged trees had previous wounds, but they gave no duration over which this damage had accumulated. Similarly Büchsenmeister (1995) reported 6.2 million P. abies stems with repeat damage as compared to 10 million stems with first-time damage in Austrian inventory surveys, but there was no indication of how old were the previous wounds and whether some wounds might have become invisible due to healing. For P. abies in Austria, Vospernik (2006) found the probability of new bark-stripping to be positively related to the percentage of previous barkstripping.

The cause of repeat woundings on individual trees could be that these trees yield bark that is easier to obtain due to their position and lack of branches, or is of better food quality or 
taste, or that the sight of fresh wounds is a cue stimulating deer to bark-strip again. These causes may lead to differences in incidence between stands of different age or tree species (Gill (1992), but as yet no study has related repeat wounding to any variation in bark quality between the individual trees of a stand. Månsson \& Jarnemo (2013) did show that newly bark-stripped $P$. abies trees had fewer branches and thinner bark than undamaged ones, so potentially were more likely to suffer repeat wounding. Saint-Andrieux et al. (2009) found that sharp early-summer peaks in bark-stripping by red deer on Fagus sylvatica coincided with the bark being then more easy to peel, but did not consider that variation in bark qualities between individual trees affected their vulnerability. Faber (1996) also showed a sharp peak in bark stripping by moose on $P$. sylvestris in spring, which coincided both with a peak in the starch and total carbohydrate content of the bark and the needs of the moose for roughage.

Selectivity for smaller trunks in bark-stripping has been found in many different studies on various ungulate species, but our study is the first to estimate this for red deer and $P$. sitchensis. Smaller trees being selected would result in less final damage if these small trees were to die disproportionately before the stands are felled. Our sites gave no evidence of such differential mortality. Partly this arose due to few trees dying at many of the sites, but also death rates for bark-stripped trees were usually similar to death rates for all trees on a site, as shown by comparing incidences calculated on initial and final tree numbers (Table 7). Moreover at a few sites the mortality of bark-stripped trees was lower than of the whole crop, e.g. EW2 (12 died of 64 bark-stripped trees cf. 40 died of 156 total trees). At this site many trees were wounded in the early outbreaks of bark-stripping, and were the bigger trees on the plots.

Healing of the Glenbranter bark-stripping wounds was very dependent on their size, as reported after 15 years of observations (Welch et al. 1997). But now we have found that many large wounds with area $>180 \mathrm{~cm}^{2}$ continued to heal after reaching 15 years age; $54 \%$ had healed fully at 15 years rising to $80 \%$ at 20 years age (Table 5). No comparable studies on the healing of bark-stripping wounds inflicted by deer on $P$. sitchensis have been reported, but Gregory (1986) found for spruce wounds 8-14 years old that more stain had developed when their area exceeded $300 \mathrm{~cm}^{2}$ than around wounds smaller than this, and that the mean extent of stain around wounds $<100 \mathrm{~cm}^{2}$ in area was small, with many wounds having no stain. Also length of decay was strongly related to wound length in P. contorta (Arhipova et al. 2015), and the frequency of fungal infection (Cylindrobasidium evolvens, Stereum sanguinolentum) was positively correlated with the size of bark wounds on P. abies caused by moose (Vasiliauskas et al. 1996). Occlusion and apparent healing of wounds does not necessarily mean there is no decay in the xylem below; in two felled logs (Welch et al. 2008) serious rot had developed below wounds that had never been judged decayed in our yearly recording, and the very large wound on tree 4515, though soon found rotten, had completely healed 16 years after wounding (Table 6).

Bark-stripping occurs largely in winter in Glenbranter (Welch el al. 1987) and is done just rarely by the red deer, since conifer bark was not found in any of the 283 rumens obtained from deer shot in the forest area (Staines et al. 1985). A likely explanation for this is that the deer strip bark during snow storms when the forest stalkers are unable to reach the forest compartments in which the deer shelter. Also in these conditions with deep snow the deer have difficulty in obtaining their normal forage of graminoids and ericoids. Other studies on bark-stripping have taken place in landscapes and silvicultural systems quite different to the Sitka spruce plantations of Western Scotland, but for red and roe deer in Austrian broad-leaved forests the availability of forage also much affected bark-stripping, this 
occurring throughout the year (Reimoser \& Gossow 1996). Likewise in P. abies plantations in Sweden damage was negatively related to the availability of forage from the field and shrub layers within the plantations and in the surrounding agricultural land (Jarnemo et al. 2014). These authors recommend that forest managers increase the availability of forage within the plantations in order to reduce bark-stripping and also provide some areas that give hiding cover or shelter for the deer but are not vulnerable to deer damage.

For British forest managers we can suggest some practical guidelines for reducing potential financial losses due to bark-stripping. First, our results show that the forest stages that would give most long-term benefit from protection are the pre-thicket and young thicket stands since in them the most-advanced trees likely to produce green good-quality logs are more liable to be wounded than in older stands. Second, sites that have incurred intense damage are more at risk in the years immediately following than sites where damage has been negligible or minor. This observed continuation of bark-stripping could result from obvious recent wounds being cues that stimulate the deer to eat bark again. Until researchers have shown that this does not happen, managers should avoid brashing and other activities that leave large bark wounds in vulnerable stands.

For future research we suggest studies in stands that have recently experienced substantial bark-stripping, to relate damage to tree and bark qualities, such as chemical composition, peelability, roughness and thickness. To tackle the problem of wounds being cues for further damage, they could be experimentally hidden or the wounded trunks removed, then the sites further monitored for a year. It would also be useful to find out exactly when bark-stripping occurred in the vulnerable winter and spring seasons, by carrying out very regular monitoring in a few stands recording bark peelability, snow-lie and other weather features that might confine deer in sheltered places.

\section{Acknowledgements}

We are grateful to many people who haye assisted in the Glenbranter study since 1978, both staff of the Forestry Commission, owners of the forest, and staff of the Centre for Ecology \& Hydrology (formerly Institute of Terrestrial Ecology). For the first ten years the study included research on the activity and behaviour of the red and roe deer in the plantations, and the main field work was carried out jointly by deer researchers, David Catt and Dr (later Professor) Brian Staines, and the present authors. We are also indebted to Dorian Moss, Don French and David Elston for at various times guiding our planning, data handling and statistics, and to Manuel Hinge and Phil Ratcliffe (deer) and Sandy Cram and Fred Last (forestry) for expert advice.

\section{References}

Akashi, N. \& Nakashizuka, T. 1999. Effects of bark-stripping by Sika deer (Cervus nippon) on population dynamics of a mixed forest in Japan. Forest Ecology \& Management 113: 7582.

Akashi, N. \& Terazawa, K. 2005. Bark-stripping damage to conifer plantations in relation to the abundance of Sika deer in Hokkaido, Japan. Forest Ecology \& Management 208: 77-83. 
Arhipova, N., Jansons, A., Zaluma, A., Gaitnieks, T., Vasaitis, R. 2015. Bark stripping of Pinus contorta caused by moose and deer: wounding patterns, discoloration of wood, and associated fungi. Canadian Journal of Forest Research 45: 1434-1438.

Büchsenmeister, R. 1995. [The current situation as regards peeling damage in the forest: Austrian Forest Inventory 1986/90]. Förderungsdienst 43: 312-320.

Edwards, T. \& Kenyon, W. 2013. Wild Deer in Scotland. SPICe Briefing for the Scottish Parliament. Edinburgh: SPICe.

Faber, WE. 1996. Bark stripping by moose on young Pinus sylvestris in South-central Sweden. Scandinavian Journal of Forest Research 11: 300-306.

Faber, WE. \& Thorson, EM. 1996. Bark stripping of young Pinus sylvestris by Alces alces on the individual, stand, and landscape level in Sweden. Canadian Journal of Forest Research 26: 2109-2114.

Gill, RMA. 1992. A review of damage by mammals in North Temperate forests. I. Deer. Forestry 65: 145-169.

Gregory, SC. 1986. The development of stain in wounded Sitka spruce stems. Forestry 65: 145-169.

Inveraray \& Tyndrum Deer Management Group 2016. Deer Management Plan: Background Information, 45 pp. Inveraray.

Jarnemo, A., Minderman, J., Bunnefeld, N., Zidar, J. \& Månsson, J. 2014. Managing landscapes for multiple objectives: alternative forage can reduce the conflict between deer and forestry. Ecosphere 5, Issue 8: 1-14.

Månsson, J. \& Jarnemo, A. 2013. Bark-stripping on Norway spruce by red deer in Sweden: level of damage and relation to tree characteristics. Scandinavian Journal of Forest Research 28: $117-125$.

Murphy, V., Carden, RF., Harrison, S., O`Halloran, J., Irwin, S. \& Butler, F. 2013. Deer in Irish commercial forests. Irish Forestry 70: 91-103.

Reimoser, F. \& Gossow, H. 1996. Impact of ungulates on forest vegetation and its dependence on the silvicultural system. Forest Ecology \& Management 88: 107-119.

Saint-Andrieux, C., Bonenfant, C., Toïgo, C., Basille, M. \& Klein, F. 2009. Factors affecting beech Fagus sylvatica bark stripping by red deer Cervus elaphus in a mixed forest. Wildlife Biology 15: 187-196.

Staines, BW., Welch, D., Catt, DC., Scott, D. \& Hinge, MDC. 1985. Habitat use and feeding by deer in Sitka spruce plantations. Annual Report of the Institute of Terrestrial Ecology for 1984: 12-16.

Vasiliauskas, R., Stenlid, J. \& Johansson, M. 1996. Fungi in bark-peeling wounds of Picea abies in central Sweden. European Journal of Forest Pathology 26: 285-296.

Verhayden, H., Ballon, P. Bernard, V. \& Saint-Andrieux, C. 2006. Variations in barkstripping by red deer Cervus elaphus across Europe. Mammal Review 36: 217-234. 
Vospernik, S. 2006. Probability of bark stripping damage by red deer (Cervus elaphus) in Austria. Silva Fennica 40: 589-601.

Welch, D., Scott, D. \& Staines, BW. 1997. Bark stripping damage by red deer in a Sitka spruce forest in western Scotland. III. Trends in wound condition. Forestry 70: 113-120.

Welch, D. \& Scott, D. 1998. Bark stripping damage by red deer in a Sitka spruce forest in western Scotland. IV. Survival and performance of wounded trees. Forestry 71: 225-235.

Welch, D. \& Scott, D. 2008. An estimate of timber degrade in Sitka spruce due to bark stripping by deer in a Scottish plantation. Forestry 81: 489-497.

Welch, D., Staines, BW., Scott, D. \& Catt, DC. 1987. Bark stripping damage by red deer in a Sitka spruce forest in western Scotland. I. Incidence. Forestry 60: 249-262.

Welch, D., Staines, BW., Scott, D. \& Catt, DC. 1988. Bark stripping damage by red deer in a Sitka spruce forest in western Scotland. II. Wound size and position. Forestry 61: 245-254.

Welch, D., Staines, BW., Catt, DC. \& Scott, D. 1990. Habitat usage by red (Cervus elaphus) and roe (Capreolus capreolus) deer in a Scottish Sitka spruce plantation. Journal of Zoology 221: 453-476.

Yokoyama, S., Maeji, I., Ueda, T., Ando, M. \& Shibata, E. 2001. Impact of bark stripping by sika deer, Cervus nippon, on subalpine coniferous forests in central Japan. Forest Ecology and Management 140: 93-99.

\section{List of Figure Captions}

Figure 1. Yearly incidences of bark-stripping for three stand types based on their age when monitoring began (blue $\bullet=$ establishment, red $\mathbf{\square}=$ pre-thicket $\&$ thicket, green $\diamond=$ pole $\&$ high forest; means for the latter two types are presented only when they each had at least five sites).

Figure 2. Timing of repeat bark-stripping, shown by occurrence of different-length intervals between woundings, for 194 trees at the establishment and pre-thicket/thicket sites. 
Table 1. Incidence of intense bark-stripping, as measured by occurrence of $>\mathbf{2} \%$ of trees at a site being wounded in a year, and by sequences of such wounding and mean tree age when these episodes occurred.

\begin{tabular}{|c|c|c|c|c|}
\hline Site & $\begin{array}{c}\text { Years of } \\
\text { Observation* }\end{array}$ & $\begin{array}{l}\text { \% Occurrence } \\
\text { of } \\
>2 \% \text { in year } \\
\text { bark-stripping } \\
\text { in years } \\
\text { available }\end{array}$ & $\begin{array}{c}\text { Longest } \\
\text { Sequence } \\
\text { of } \\
\text { intense } \\
\text { bark-stripping } \\
\text { (yrs) }\end{array}$ & $\begin{array}{c}\text { Average } \\
\text { Age when } \\
\text { suffering } \\
\text { intense } \\
\text { bark-stripping } \\
\text { (yrs) }\end{array}$ \\
\hline EW1 & 34 & 0 & - & \\
\hline EW2 & 33 & 33 & 6 & 18 \\
\hline EW4 & 35 & 6 & 1 & 24 \\
\hline EW5 & 27 & 41 & 4 & 22 \\
\hline ED4 & 34 & 15 & 2 & 19 \\
\hline ED6 & 27 & 26 & 2 & 25 \\
\hline ED9 & 28 & 46 & 4 & 17 \\
\hline EC2 & 35 & 3 & 1 & 26 \\
\hline EC5 & 34 & 21 & 1 & 27 \\
\hline EC6 & 32 & 6 & 1 & 16 \\
\hline EC7 & 10 & 0 & - & - \\
\hline EHN & 29 & 14 & 3 & 16 \\
\hline ED3 & 34 & 12 & 2 & 19 \\
\hline EH1 & 35 & 14 & 2 & 23 \\
\hline EH5 & 33 & 3 & 1 & 41 \\
\hline EH6 & 22 & 5 & 1 & 21 \\
\hline TW1 & 25 & 28 & 2 & 36 \\
\hline TD2 & 32 & 28 & 2 & 38 \\
\hline TD4 & 32 & 44 & 10 & 34 \\
\hline TC2 & 25 & 12 & 1 & 23 \\
\hline TC4 & & 0 & - & - \\
\hline TB4 & 18 & 33 & 2 & 34 \\
\hline TB5 & 25 & 8 & 1 & 22 \\
\hline PB1 & 11 & 9 & 1 & 36 \\
\hline PB3 & 14 & 29 & 1 & 39 \\
\hline PM2 & 10 & 0 & - & - \\
\hline HB1 & 11 & 0 & - & - \\
\hline HB4 & 10 & 0 & - & - \\
\hline
\end{tabular}

* For Establishment sites (codes EW1 to EHN) includes only years once the tree crop became 6 years old. 
Table 2. Incidences of repeated bark-stripping for individual sites (includes only sites with $>30$ years of observations, and counts only repeat damage within 20 yr of initial damage).

\begin{tabular}{|c|c|c|c|c|}
\hline Site & $\begin{array}{l}\text { Number of trees } \\
\text { bark-stripped } \\
\text { in first } 20 \mathrm{yr} \\
\text { of observations }\end{array}$ & $\begin{array}{c}\text { \% Incidence } \\
\text { of bark-stripping } \\
\text { in first } 20 \mathrm{yr} \\
\text { of observations } \\
\text { on trees } \\
\text { initially present }\end{array}$ & $\begin{array}{l}\text { Numbers of trees } \\
\text { bark-stripped again } \\
\text { of those barked } \\
\text { in first } 20 \text { yr of } \\
\text { observations }\end{array}$ & $\begin{array}{l}\text { \% Incidence } \\
\text { of repeat barking } \\
\text { on trees barked } \\
\text { in first } 20 \text { yr of } \\
\text { observations }\end{array}$ \\
\hline EW1 & 10 & 7.8 & 2 & 20.0 \\
\hline EW2 & 56 & 35.9 & 17 & 37.8 \\
\hline EW4 & 5 & 4.8 & 1 & 20.0 \\
\hline EW5 & 11 & 12.5 & 3 & 27.3 \\
\hline ED4 & 19 & 13.4 & 6 & 33.3 \\
\hline ED6 & 18 & 13.7 & 6 & 40.0 \\
\hline ED9 & 38 & 26.8 & 15 & 40.5 \\
\hline EC2 & 4 & 2.9 & 2 & 50.0 \\
\hline EC5 & 17 & 11.3 & 6 & 35.3 \\
\hline EC6 & 13 & 10.7 & 3 & 25.0 \\
\hline EHN & 22 & 17.2 & 6 & 37.5 \\
\hline ED3 & 23 & 13.8 & 6 & 35.3 \\
\hline EH1 & 19 & 11.0 & 6 & 42.9 \\
\hline EH5 & 10 & 5.5 & 3 & 42.9 \\
\hline TD2 & 25 & 13.7 & 14 & 63.6 \\
\hline TD4 & 66 & 37.5 & 29 & 58.0 \\
\hline
\end{tabular}

Table 3. Selectivity in bark-stripping shown by mean differences between the girth of wounded trunks and all trunks on plots with wounding, for $10-\mathrm{cm}$ classes of plot mean girth. Number of occurrences of wounding (n) and standard errors are given for each plot-girth class for three types of stand based on age in 1978 (0-8 yrs old establishment; 9-28 yrs old - pre-thicket \& thicket; pole \& high forest 29-57 yrs old).

\begin{tabular}{|c|c|c|c|c|c|c|}
\hline $\begin{array}{l}\text { Class of } \\
\text { Plot Mean }\end{array}$ & & $\begin{array}{c}\text { blishment } \\
\text { Mean }\end{array}$ & Pre-th & $\begin{array}{l}\text { ket \& Thicket } \\
\text { Mean }\end{array}$ & Pole & $\begin{array}{l}\text { High Forest } \\
\text { Mean }\end{array}$ \\
\hline Girth & $\mathrm{n}$ & Difference & $\mathrm{n}$ & Difference & $\mathrm{n}$ & Difference \\
\hline $0-19$ & 86 & $1.5 \pm 0.7$ & 16 & $-3.9 \pm 1.2$ & & \\
\hline $20-29$ & 84 & $-4.6 \pm 1.0$ & 71 & $-3.4 \pm 1.0$ & 2 & -6.5 \\
\hline $30-39$ & 53 & $-8.8 \pm 1.7$ & 106 & $-5.4 \pm 1.1$ & 26 & $-2.0 \pm 2.3$ \\
\hline $40-49$ & 47 & $-13.9 \pm 1.9$ & 143 & $-6.3 \pm 1.2$ & 42 & $-6.8 \pm 1.9$ \\
\hline 50-59 & 51 & $-17.1 \pm 2.2$ & 63 & $-6.1 \pm 1.9$ & 12 & $-3.6 \pm 4.0$ \\
\hline $60-69$ & 50 & $-16.7 \pm 2.4$ & 25 & $-7.4 \pm 3.1$ & 9 & $-17.1 \pm 7.0$ \\
\hline 70- & 38 & $-25.4 \pm 2.8$ & 13 & $-10.6 \pm 7.4$ & & \\
\hline
\end{tabular}


Table 4. Mean times elapsed between bark-stripping and the wounds being classed as healed, for trees of two stand types in three wound size classes, with standard errors and ranges of times.

\begin{tabular}{|c|c|c|c|c|}
\hline Stand type & $\left(\mathrm{cm}^{2}\right)$ & $\begin{array}{c}\text { Wound size } \\
\text { of } \\
\text { wounds }\end{array}$ & $\begin{array}{l}\text { Number } \\
\text { elapsed } \\
\text { (yrs) }\end{array}$ & $\begin{array}{c}\text { Mean Time } \\
\text { healing times } \\
\text { (yrs) }\end{array}$ \\
\hline Establishment & $\begin{array}{r}<60 \\
60-179 \\
>180\end{array}$ & $\begin{array}{r}125 \\
50 \\
21\end{array}$ & $\begin{array}{r}7.1 \pm 0.3 \\
10.1 \pm 0.6 \\
12.8 \pm 0.8\end{array}$ & $\begin{array}{l}2-18 \\
3-25 \\
8-21\end{array}$ \\
\hline $\begin{array}{l}\text { Pre-thicket \& } \\
\text { Thicket }\end{array}$ & $\begin{array}{r}<60 \\
60-179 \\
>180\end{array}$ & $\begin{array}{r}113 \\
67 \\
23\end{array}$ & $\begin{array}{r}8.0 \pm 0.2 \\
10.1 \pm 0.4 \\
11.3 \pm 0.7\end{array}$ & $\begin{array}{l}1-20 \\
5-19 \\
8-15\end{array}$ \\
\hline
\end{tabular}


Table 5. Progress of healing of different-sized bark-stripping wounds measured at 10, 15 and 20 years after wounding for trees of different ages at wounding and different stand types.

\begin{tabular}{|c|c|c|c|c|}
\hline $\begin{array}{l}\text { Wound } \\
\text { Size w }\end{array}$ & $\begin{array}{c}\text { Time after } \\
\text { wounding (yr) }\end{array}$ & $\begin{array}{l}\text { Number of } \\
\text { wounds }\end{array}$ & $\begin{array}{l}\text { \% healed } \\
\text { fully }\end{array}$ & $\begin{array}{c}\% \\
\text { not healed }\end{array}$ \\
\hline \multicolumn{5}{|c|}{ Trees of all ages } \\
\hline \multirow{3}{*}{$<60 \mathrm{~cm}^{2}$} & 10 & 266 & 78 & 22 \\
\hline & 15 & 252 & 98 & 2 \\
\hline & 20 & 252 & 100 & 0 \\
\hline \multirow[t]{3}{*}{$60-179 \mathrm{~cm}^{2}$} & 10 & 160 & 48 & 52 \\
\hline & 15 & 136 & 90 & 10 \\
\hline & 20 & 131 & 96 & \\
\hline \multirow[t]{3}{*}{$>180 \mathrm{~cm}^{2}$} & 10 & 75 & 17 & 83 \\
\hline & 15 & 54 & 54 & 46 \\
\hline & 20 & 41 & o & 20 \\
\hline \multicolumn{5}{|c|}{$\underline{\text { Trees }<20 \mathrm{yr} \text { old at wounding }}$} \\
\hline \multirow{3}{*}{$<60 \mathrm{~cm}^{2}$} & 10 & 138 & 88 & 12 \\
\hline & 15 & 137 & 99 & 1 \\
\hline & 20 & 137 & 100 & 0 \\
\hline \multirow[t]{3}{*}{$60-179 \mathrm{~cm}^{2}$} & 10 & & 55 & 45 \\
\hline & 15 & 72 & 88 & 12 \\
\hline & & 60 & 94 & 6 \\
\hline \multirow[t]{6}{*}{$>180 \mathrm{~cm}^{2}$} & & 29 & 24 & 76 \\
\hline & & 29 & 55 & 45 \\
\hline & 0 & 25 & 72 & 28 \\
\hline & 10 & 128 & 68 & 32 \\
\hline & 15 & 115 & 98 & 2 \\
\hline & 20 & 115 & 99 & 1 \\
\hline \multirow[t]{3}{*}{$60-179 \mathrm{~cm}^{2}$} & 10 & 84 & 42 & 58 \\
\hline & 15 & 64 & 92 & 8 \\
\hline & 20 & 62 & 98 & 2 \\
\hline \multirow[t]{3}{*}{$>180 \mathrm{~cm}^{2}$} & 10 & 46 & 13 & 87 \\
\hline & 15 & 25 & 52 & 48 \\
\hline & 20 & 16 & 94 & 6 \\
\hline
\end{tabular}


Table 6. Size and progress in healing of all very large wounds $\left(>500 \mathrm{~cm}^{2}\right)$ incurred at establishment and pre-thicket/thicket sites up to 2014.

\begin{tabular}{|c|c|c|c|c|c|c|c|c|}
\hline \multirow[t]{2}{*}{ Site } & \multirow[t]{2}{*}{ Tree } & \multirow{2}{*}{$\begin{array}{c}\text { Year } \\
\text { Wounded } \\
\text { /Age }\end{array}$} & \multirow{2}{*}{$\begin{array}{c}\text { Girth } \\
\text { (cm) } \\
\text { when } \\
\text { wounded }\end{array}$} & \multirow{2}{*}{$\begin{array}{l}\text { Wound } \\
\text { length } \\
\mathrm{x} \\
\text { breadth } \\
(\mathrm{cm})\end{array}$} & \multicolumn{3}{|c|}{ Years after wounding } & \multirow{2}{*}{$\begin{array}{c}\text { Year } \\
\text { finally } \\
\text { observed }\end{array}$} \\
\hline & & & & & $\begin{array}{c}\text { xylem } \\
\text { occluded }\end{array}$ & $\begin{array}{c}\text { rot } \\
\text { seen }\end{array}$ & healed & \\
\hline EW5 & 1912 & $2009 / 30$ & 65 & $38 \times 14$ & $>3$ & $>3$ & & 2012 \\
\hline ED6 & 1617 & 2011/32 & $37 w$ & $56 \times 9$ & $>1$ & $>1$ & & 2012 \\
\hline ED6 & 1666 & $2009 / 30$ & 73 & $54 \times 13$ & $>3$ & $>3$ & 3 & 2012 \\
\hline ED6 & 1720 & $2004 / 25$ & 27 & $60 \times 14$ & $>8$ & $>8$ & & 2012 \\
\hline ED9 & 1443 & $1991 / 13$ & 27 & $70 \times 10$ & 6 & & $>24$ & 2015 \\
\hline ED9 & 1443 & 1997/19 & 47 & $44 \times 13$ & 7 & 18 & $>18$ & 2015 \\
\hline EC5 & 2221 & $1995 / 21$ & 32 & $54 \times 32$ & $>17$ & 8 & $>17$ & 2013D \\
\hline EC5 & 2228 & $1995 / 21$ & $35 w$ & 53x10 & 17 & 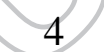 & $>17$ & 2013D \\
\hline EH1 & 2675 & 1987/19 & 20 & 51x15 & 7 & $>7$ & $>7$ & 1995D \\
\hline EH1 & 2679 & $1993 / 25$ & 58 & $46 \times 6$ & & $>5$ & $>5$ & $1999 \mathrm{~F}$ \\
\hline EH1 & 2679 & $1993 / 25$ & 58 & $48 x 7$ & & $>5$ & $>5$ & $1999 \mathrm{~F}$ \\
\hline EH1 & 2683 & $2009 / 41$ & 59 & $88 \times 14$ & $>4$ & $>4$ & $>4$ & $2014 \mathrm{~F}$ \\
\hline EH5 & 3472 & $1987 / 20$ & 32 & $94 \times 15$ & $>11$ & 2 & $>11$ & 1999F \\
\hline EH5 & 3476 & $2009 / 42$ & 54 & $42 \times 20$ & $>3$ & $>3$ & $>3$ & $2013 F$ \\
\hline EH6 & 3668 & $1983 / 16$ & 18 & $95 \times 14$ & $>19$ & $>19$ & $>19$ & $2003 \mathrm{~F}$ \\
\hline TW1 & 3928 & 1999/31 & 66 & $73 \times 13$ & $>4$ & 4 & $>4$ & $2004 \mathrm{~F}$ \\
\hline TD2 & 4309 & $1991 / 28$ & 50 & $43 \times 10$ & 8 & $>20$ & 9 & 2011 \\
\hline TD2 & 4309 & $1991 / 28$ & 50 & $45 \times 8$ & 9 & $>20$ & 10 & 2011 \\
\hline TD2 & 4318 & $1999 / 36$ & 48 & 27x21 & 7 & $>20$ & $>12$ & 2011 \\
\hline TD2 & 4323 & $1996 / 33$ & 22 & $72 \times 7$ & 12 & $>15$ & $>15$ & 2011 \\
\hline TD2 & 4328 & $2002 / 39$ & 74 & $84 \times 18$ & $>9$ & 2 & $>9$ & 2011 \\
\hline TD4 & 4515 & $1983 / 24$ & 31 & $61 \times 10$ & 14 & 2 & 16 & $2012 \mathrm{~F}$ \\
\hline TD4 & 4535 & $1989 / 30$ & 26 & 60x19 & $>8$ & 6 & $>8$ & 1998D \\
\hline TD4 & 4546 & $2008 / 49$ & $23 w$ & $52 \times 12$ & $>2$ & $>2$ & $>2$ & 2011D \\
\hline TC2 & 4705 & $1986 / 28$ & 31 & $26 \times 20$ & $>12$ & $>12$ & $>12$ & $1999 \mathrm{~F}$ \\
\hline TB5 & 5314 & $1984 / 25$ & 28 & 52x15 & $>12$ & $>12$ & $>12$ & 1997D \\
\hline
\end{tabular}

w shows weak trunk wounded of a multiple-trunk tree

$>$ shows event had not happened at this number of years after wounding

D shows tree/trunk was dead at the last observation

F shows tree had been felled or was blown down at last observation

Trees 2679 and 4309 suffered two wounds in the same year, their combined area reaching the $500 \mathrm{~cm}^{2}$ qualification 
Table 7. Accumulated impact of bark-stripping (BK) compared to theoretical impact, this latter based on annual rates and hence not allowing for repeat damage and tree deaths (qualification: at least 25 years of observation at site). Large wounds were ones $>180 \mathrm{~cm}^{2}$.

\begin{tabular}{|c|c|c|c|c|c|c|}
\hline Site & $\begin{array}{c}\text { Mean \% } \\
\text { Trees BK } \\
\text { yr }^{-1}\end{array}$ & $\begin{array}{c}\text { Duration } \\
\text { of } \\
\text { damage } \\
\text { observations } \\
\text { yrs }\end{array}$ & $\begin{array}{l}\text { Theoretical } \\
\% \text { trees } \\
\text { BK } \\
\text { of initial } \\
\text { stock }\end{array}$ & $\begin{array}{l}\text { Actual } \\
\% \text { trees } \\
\text { BK } \\
\text { of initial } \\
\text { stock }\end{array}$ & $\begin{array}{l}\text { Actual } \\
\% \text { trees } \\
\text { BK } \\
\text { of final } \\
\text { stock }\end{array}$ & $\begin{array}{c}\% \text { trees } \\
\text { BK and with } \\
\text { large wounds, } \\
\text { of final } \\
\text { stock }\end{array}$ \\
\hline$\overline{\text { EW1 }}$ & 0.32 & 34 & 11.0 & 8.2 & 9.6 & 3.4 \\
\hline EW2 & 1.92 & 32 & 61.5 & 41.0 & 44.8 & 11.2 \\
\hline EW4 & 0.32 & 34 & 10.7 & 6.7 & 6.6 & 0.0 \\
\hline EW5 & 1.73 & 26 & 44.9 & 29.4 & 32.0 & 2.5 \\
\hline ED4 & 0.78 & 33 & 25.7 & 14.7 & 16.2 & 2.6 \\
\hline ED6 & 1.29 & 26 & 33.4 & 24.6 & 27.2 & 5.6 \\
\hline ED9 & 1.72 & 30 & 51.6 & 36.4 & 36.9 & 10.8 \\
\hline EC2 & 0.22 & 34 & 7.6 & 5.7 & 6.7 & 1.7 \\
\hline EC5 & 0.94 & 34 & 31.8 & 22.2 & 24.6 & 4.4 \\
\hline EC6 & 0.60 & 32 & 19.0 & 14.4 & 14.5 & 0.9 \\
\hline EHN & 0.90 & 29 & 26.2 & 23.4 & 23.4 & 5.2 \\
\hline ED3* & 0.63 & 34 & 21.5 & 13.8 & 15.4 & 0.0 \\
\hline EH1* & 0.72 & 35 & 25.1 & 10.5 & 11.8 & 2.9 \\
\hline EH5* & 0.32 & 33 & 10.6 & 5.4 & 8.3 & 2.1 \\
\hline TW1* & 1.34 & 25 & 33.4 & 23.1 & 20.5 & 1.7 \\
\hline TD2* & 1.35 & 33 & 44.6 & 27.3 & 29.1 & 8.8 \\
\hline TD4* & 2.29 & & 75.7 & 42.4 & 45.4 & 11.3 \\
\hline TC2* & 0.87 & & 21.6 & 14.1 & 14.0 & 0.8 \\
\hline TB5* & 0.82 & & 20.4 & 15.0 & 12.0 & 0.0 \\
\hline
\end{tabular}

* shows older sites at which some damage probably occurred before observations began; for them the calculated theoretical damage rate is based only on our observations and uses the number of trees at their start. 

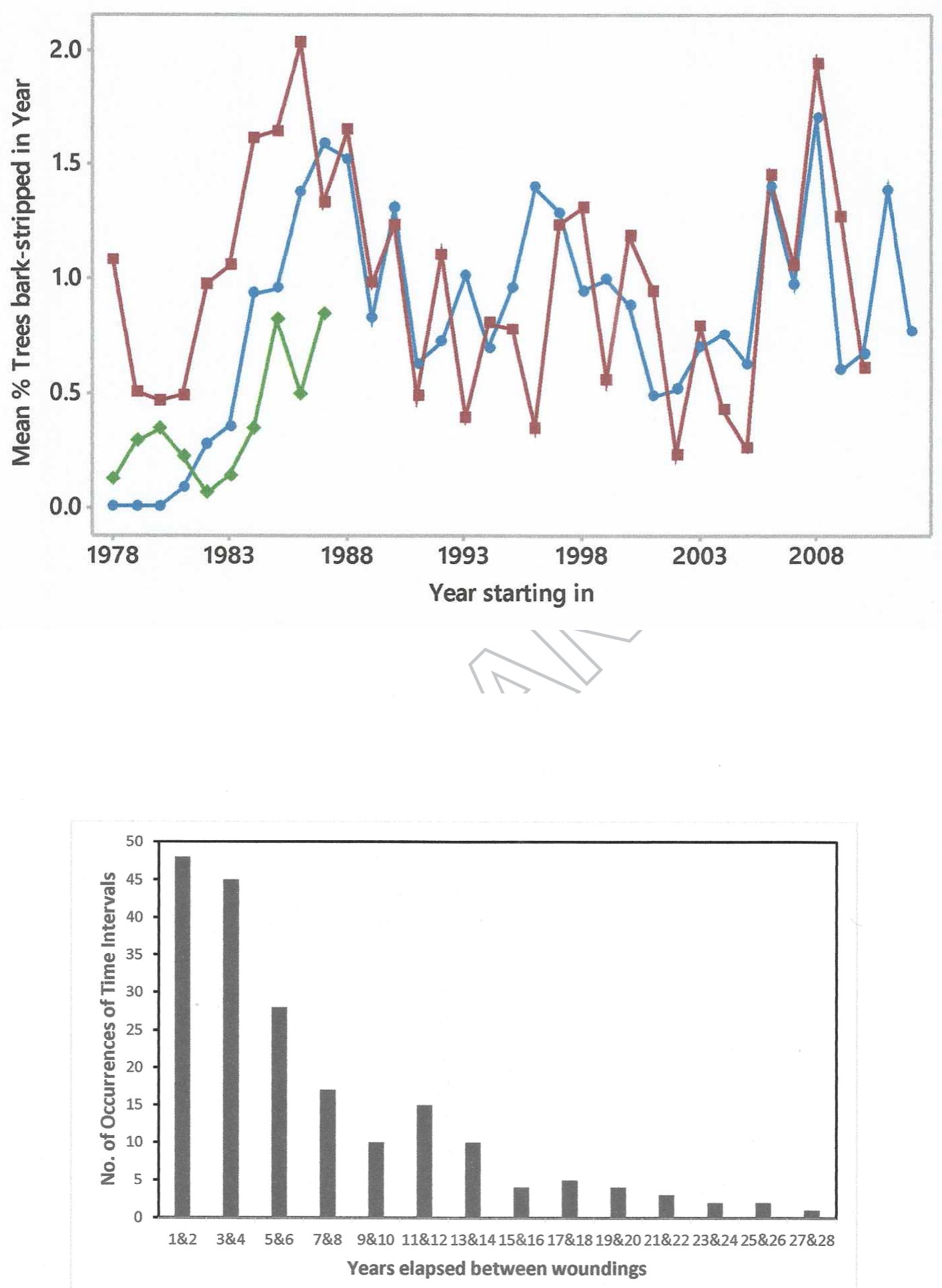